\title{
A Qualitative Study on Family Meals in Western Samoa with Special Reference to Child Nutrition
}

\author{
By SUSAN HOLMES \\ South Pacific Health Service, Headquarters Office, Suva, Fiji \\ (Received 22 October 1953)
}

Early in 195 I a survey of eating habits was made in Western Samoa by the South Pacific Health Service. The purpose of the study was to observe the factors that influence the nutrition of the young Samoan child. In spite of a rapidly increasing population, the existing indigenous food supplies provide for the adequate nutrition of the people living in most areas. There are a few small islands where over-population is reflected by a poorer standard of nutrition, but they are the exception rather than the rule. Nutrition appears to be influenced more by dietary customs than by the availability of food.

There are no cows in the villages in Samoa and so no fresh milk, but no kwashiorkor has been described from there. It is clear, therefore, that the problem of feeding the weanling child cannot be as acute as it is in many other parts of the tropics. There are, however, no grounds for complacency. In Fiji, where conditions among Fijians, but not among Indians, are much the same as in Samoa, sixteen cases of kwashiorkor among Fijian children have been described by Manson-Bahr (1952).

In a report on the nutrition of Samoans, Bell (1950) considered that the low-protein diet of weanlings and toddlers caused them to lose condition and become susceptible to intercurrent infections.

Although mortality statistics for Western Samoa are not very accurate the high percentage of total deaths reported for the age groups from 6 months to 2 years are very suggestive. The mean percentage of total deaths for different ages for the years I947-50 inclusive* is shown below:

$\begin{array}{lrrr}\text { Under I week } & 4 \cdot 17 & \text { I-2 years } & 12 \cdot 83 \\ \text { I week-I month } & I \cdot 93 & 2-3 \text { years } & 4 \cdot 69 \\ \text { I-3 months } & 2 \cdot 55 & 3-4 \text { years } & 2 \cdot 27 \\ \text { 3-6 months } & 4 \cdot 7 I & 4-5 \text { years } & I \cdot 57 \\ \text { 6-I2 months } & \text { II } 54 & & \end{array}$

Marples (I950-I) investigated the heights and weights of 1329 Samoan children under 12 years of age, and found that the weights of infants up to 6 months were above the average for New Zealand, but that in the second 6 months they were far below it. Older children appeared to be shorter and lighter than in New Zealand. The poor appearance of many young schoolchildren provides additional evidence that the nutrition of young children is inadequate.

The present study aimed at finding means to increase the protein consumption of young children.

* Figures extracted from Western Samoan Annual Report, r95 I. 
Richards (1948), in her book Hunger and Work in a Savage Community, suggests that: 'Nutrition in its widest sense includes the whole scheme of regulations by which man's food-getting activities are organized and controlled and unless we can picture the whole nutritional system in functioning order we shall have but a one sided view of the whole.' The structure of Polynesian society reveals the need for any nutrition study to have a wide basis of this nature, for the functions of food preparation, procurement, and distribution are all intimately related with prestige within the family, the village and the island.

From the point of view of nutrition the present is a difficult time because it is easy for nutritious local foods to be replaced by imported varieties of poor quality, for new teaching in child-rearing practices to be half-adopted, and for the routine gathering and preparation of food to be disorganized by a new economy based on money. Nutritional problems often arise at such a stage of transition in the evolution of a people, but their appearance may be averted if education and medical and agricultural programmes supply the right technical assistance at the right time. Understanding of existing conditions is, however, a necessary preliminary. The present study attempts to describe some of the conditions that seem to influence the existing state of nutrition among Samoan children and makes suggestions which may prove to be of value in future programmes. The suggestions aim at providing for the most urgent nutritional needs and are based on patterns of activity observed to be common in the villages and which reliable informants agreed were prevalent in other parts of Western Samoa.

\section{EXPERIMENTAL}

\section{Background information}

The territory of Western Samoa (see Fig. 1 ) lies between the $13^{\text {th }}$ and $15^{\text {th }}$ degrees of south latitude and the 17 ist and 173 rd degrees of west longitude. It includes the main islands of Upolo and Savai' $i$, and the two smaller islands of Manono and Apolima. Upolo and Savai'i are 400 and 700 sq. miles in area, respectively, and Manono and Apolima have a total area of $\mathbf{2}$ sq. miles. The climate is tropical, there is a heavy rainfall, humid atmosphere and small range in temperature. Average daily temperatures vary between $79 \cdot 3^{\circ}$ and $84 \cdot 7^{\circ} \mathrm{F}$. and the average annual rainfall is $\mathrm{III}$ in. All the islands are covered with a luxuriant tropical growth. The main economic crops are cocoa and copra. Samoan life to-day is a mixture of an old civilization with many European ways. Sometimes an old practice has become inextricably combined with a new one borrowed from British or American life. The pride of the people in their islands causes them to extol all things Samoan, while at the same time easily adopting the American taxi, the telephone and the imported, manufactured foods which are available in the town of Apia.

Most of the observations were made on the island of Manono which lies about I mile off the western coast line of Upolu. The nearest village on the mainland is Muli'fanua, 20 miles distant from Apia, the main town in Western Samoa. Communication with Apia is by long-boat to Muli'fanua and a bus service which runs several times a day up the coast. The traders obtain most of their stores from launches of the Apia firms. 


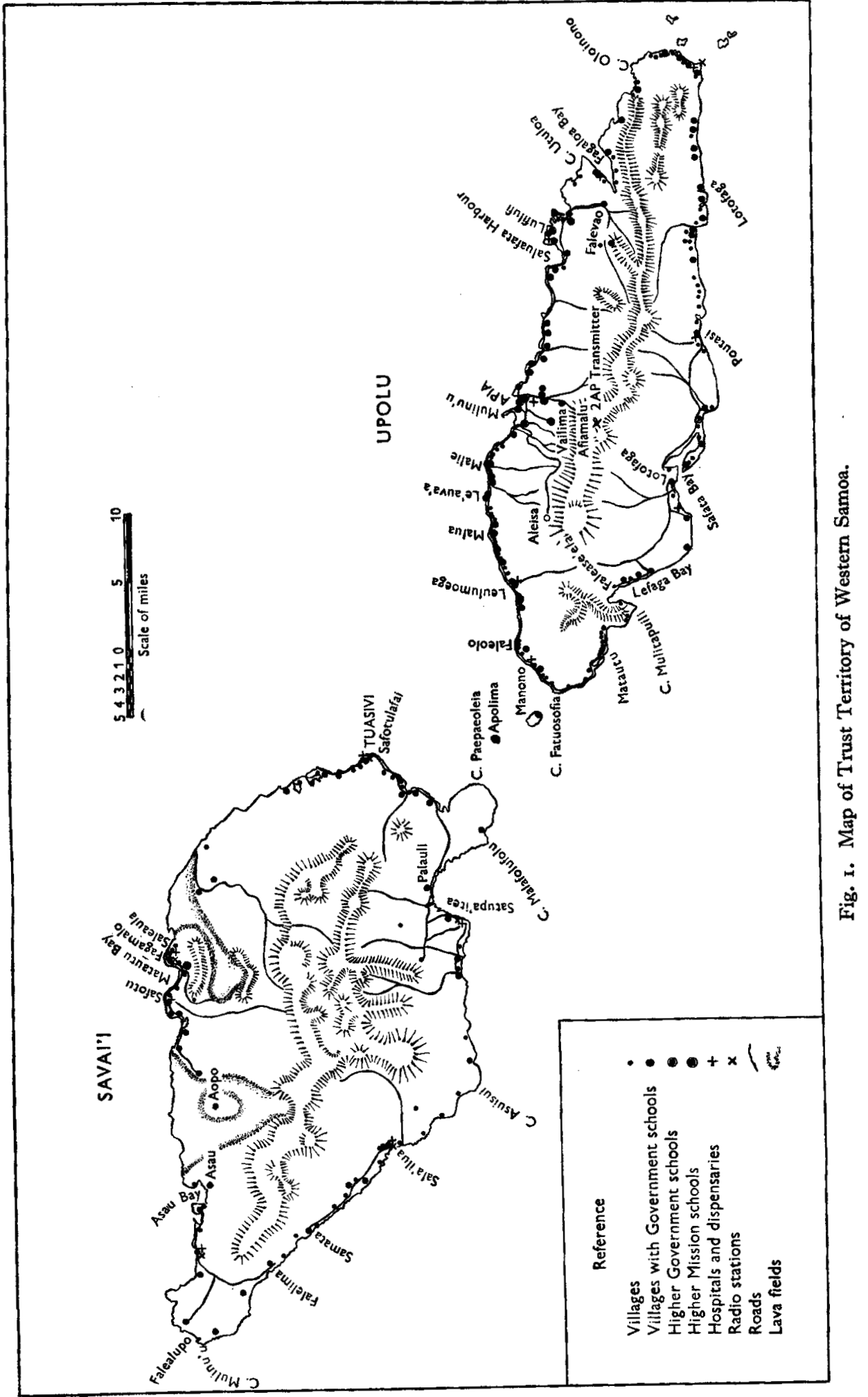


There are about 1000 people on Manono but, because it cannot support its population, many people have now taken up residence on the opposite mainland. Here the majority of the aiga (related households) have plantations where they raise taro, a staple food which cannot be grown on Manono.

The difficulties of living are many and are made worse by the total lack of running water. Most families carry their water from tanks or catchment wells in the bush. Rainwater is collected rather inefficiently from the iron-roofed churches and fales (houses). The lack of stored water is a serious problem in the dry season. Dishes cannot be washed properly, and only Sunday clothes can be kept clean. The working clothes of both children and adults for work about the fale and plantation are incredibly dirty. A spotless Sunday dress, town dress and Committee* dress are of great social importance.

Social life on the island revolves round the church. The Methodist and the London Missionary Society churches have the greatest following and there is a small group of Roman Catholics. There are five churches on the island and three at present under construction. A high proportion of the people's income must be given to the church.

Cash income is derived almost entirely from sale of copra and cocoa. Cocoa is as yet only a minor crop, but will gradually gain in importance as the recently established plantations come into bearing. The aiga of the chief fishermen sometimes sell fish in Apia.

For the month of December the cash income of the thirty-three aiga living in two villages ranged between $£_{7}$ and $£_{27}$, averaging $£_{14}$. It is understood that the rate remains fairly constant throughout the year, though income is influenced to some extent by season, and by the amount of labour which each aiga has available for work in the plantations. At the trader's store most of the people run temporary accounts which are paid off when cash is available. A family can thus make small purchases of food, cloth or cigarettes, even when ready cash is not available.

\section{Method of study}

During the study frequent visits were made to two villages on Manono which together supported a population of about 600 people. Later, some time was spent in a village at Lefaga Bay on Upolu, and visits were made to Women's Committee meetings on Upolu.

A true idea of daily food consumption was gained by making surprise visits to families during mealtimes. The preparation and cooking of food, the methods of storage and the number and kind of food utensils were frequently observed.

The feasts that are given for an expected guest are not representative of daily food consumption, but they provide an opportunity for seeing a variety of Samoan dishes and for collecting recipes. It was thus possible to observe the distribution of food

* The Samoan Women's Committee is an important village institution. During the last 20 years it has gradually taken the place of the Assembly of the Wives of Chiefs and Orators. It is composed of leading village women, who wear a distinctive uniform and meet regularly. The Committee works in close co-operation with the District Nurse, and is responsible for seeing that infant welfare and public health work is carried out in the village under the supervision of the Nurse and Assistant Medical Practitioner. 
among the family or group, and to see the women unselfconsciously feeding their children.

The trader's books at Manono were borrowed and provided useful information about the amounts and kinds of European foods that were being consumed.

Whenever possible Samoan men and women were questioned, and a series of questions was devised so phrased that the informants had fairly equal opportunities for supplying the required information.

\section{RESULTS}

\section{Food consumption}

Imported foods. Of goods purchased at the store sugar was the article most frequently bought, and salt the least frequently. Each purchase was counted as a unit. The amount was not taken into consideration because large orders were placed only when there were more people to feed. Thus a man might buy a pound tin of meat for his family to eat with breadfruit on Sunday one week and the following week-end the order might be for $3 \mathrm{lb}$. simply because some of his relatives were visiting him and had to be fed. On each occasion, the man himself would obtain only one share of meat. Even if an article of food was bought to present as a gift it would ultimately be consumed in the diet as a return gift of a similar nature. A sample of the purchasing patterns of forty-one people in one village is shown in Table $\mathbf{I}$.

Table I. Number of units* purchased in September to December 195I on behalf of forty-one people, showing the relative amounts obtained

$\begin{array}{lc}\quad \text { Item } & \text { No. of units } \\ \text { Sugar } & \text { I39 } \\ \text { Cigarettes } & 4 \mathbf{r} \\ \text { Tinned meat } & 36 \\ \text { Kerosene } & 27 \\ \text { Household goods such } & 3 \mathbf{1} \\ \text { as cloth } & \\ \text { Soap } & 25 \\ \text { Rice } & 22 \\ \text { Lard } & 17 \\ \text { Preserved milk } & 13\end{array}$

* See text above.

One-third of the money spent was for food and two-thirds for other goods, the most important items being soap, kerosene, cigarettes and tobacco. Of the foods purchased from the stores sugar was used to sweeten tea and cocoa, in making cakes for feasts and preparing the caramel sauce for kopai (flour dumpling). The amount of sugar consumed was closely related to economic status. Flour was used occasionally on Manono for making cakes, in other areas more frequently for making dumplings. Rice was cooked occasionally as a quick breakfast food and was also a popular food for children. Tinned meat, salted meat and tinned fish were eaten about once a week by most families. Greater amounts were used when fishing conditions were poor. Lard was used occasionally for frying and butter was an ingredient in cake making. Baking powder, essences, flavouring for drinks, salt and coffee were bought for N viII 3 
special occasions. Biscuits were used for feasts and were always bought by the tin. In the complete absence of fresh cow's milk, sweetened condensed milk, evaporated milk and dried milk were used by a few mothers for infant or child feeding. Condensed milk was popular because it would keep when opened. Few families could afford to buy any of the milks regularly. Sweets and chewing gum were popular with the children and adults. Chewing gum is cheap and keeps well in the tropics.

Island-produced foods. Breadfruit (Artocarpus sp.), taro (Colocasia antiquorum) and green banana (Musa sapientum var.) were the main sources of energy in the diet. Between October and January breadfruit and bananas were eaten almost exclusively. There are many ulu (breadfruit) trees on Manono and the five varieties provide a continuous supply of fruit during the summer. The weight of an $u m u$ (oven)-baked breadfruit ranges between 3 and $5 \mathrm{lb}$. It is customary to bake some fruits every day, about one and a half being allowed per head for two meals. For one family of eleven persons, comprising five children and six adults, twenty fruits were prepared. The share of the small children did not appear to count in the calculations. They were expected to receive a piece of food from the share of an adult or older child at the mealtime.

For about 9 months of the year the people depend on taro and bananas. They are grown in the Upolu plantations and are brought over to Manono by paopao (canoe) or fautasi (long-boat) on Mondays and Fridays, which are the two main days for plantation work. Bananas mature all the year round and are eaten nearly every day, usually as an addition to breadfruit or taro. Ta'amu (Xanthosoma sagittifolium) is widely grown on Manono and supplements the main taro crop. By the time the breadfruits are ripe, there is little taro left in the plantation.

Coconut cream is prepared nearly every day. About two coconuts are allowed per head daily. A man of average efficiency would produce about 3 pints of cream from twenty nuts. At one meal individuals consumed from 2 to $4 \mathrm{oz}$. of cream, baked or fluid.

The remoteness of the plantations probably explains the lack of green vegetables in the diet of the Manono people. All families who were questioned said that they did not eat palusami (green taro leaves cooked in coconut cream) more than once a week.

Pineapple, pawpaw, guava and mango are grown in most plantations, but they seldom form a main part of a meal. They are eaten irregularly, often away from home during work in the plantation.

The people are very fond of Samoan koko drink. It may be taken daily if there are enough cocoa beans, and labour to roast and pound them. The beans are taken out of the pods and dried in the sun on mats. They are then roasted on an iron sheet suspended over hot coals; they are constantly turned and when they appear dark brown and crisp, the husk is removed by hand and the beans are ground to a paste with a stone pestle in a tanoa te koko (wooden mortar). The drink is prepared by mixing the paste with boiling water and sugar. It may be taken cold or hot. Keesing (I952) says that koko drink was probably prepared for the first time in the r920's. The method of preparation appears to be a Samoan invention.

There are three head fishermen on Manono who organize the net fishing. At 
week-ends shark fishing expeditions are made. There is a plentiful supply of small fish and shellfish from the rocks and reef. Fish is consumed from four to five times a week. There are plenty of pigs, most of which are undersized. Pork is consumed only on ceremonial occasions. Every village appears to have numerous fowls. Eggs are collected to make cakes or to serve as an extra dish at a feast. Fowls are killed only for special occasions and sometimes for the Sunday $u m u$.

The traditional meal pattern. The traditional Samoan meal consists of a basic starchy food such as green bananas, taro, yam or breadfruit and a protein, fat or sweet-flavoured relish. Each piece of the starchy food is dipped into the flavouring before it is eaten. Eating is a favourite pastime and the feasting of guests has great social importance. Fowls, pigs, tins of beef and biscuits are usually reserved for such feasts. On ceremonial occasions the food is served first to the guest and male heads of the family. What is left over is collected for the leading women and finally the children.

The first meal of the day is usually taken about 8-10 a.m. and the evening meal after 6 p.m. In the interval cooked roots left over from either meal may be taken. Mealtimes differ in some of the villages. At the family meals the women divide the food and serve the head men first. The remainder is then divided among the women and children. The protein-rich delicacies are distributed according to rank and age, so that the younger children have the least opportunity for sharing the more nutritious foods. The children in the families of chiefs, pastors, chief fishermen and carpenters are likely to be better fed than the rest because their families receive regular gifts of fish, pork and poultry.

\section{Traditional methods of food preparation and cooking}

General. Samoan cooking methods are based on the principle of heat conservation. Food is cooked mainly in the traditional umu (oven) or in an ulo (pot). The pot has been recently adopted and is most commonly used in the areas of Upolu that have closer contact with European life. Keesing (1952) has said that he never observed pot-cooking during his studies of Samoan life in 1930, nor is this method mentioned by Mead (1929). For the most part, conservative methods are used. The liquid left over from cooking chicken or fish is used in soup. In the umu food is baked by dry, stored heat or it may be steamed in banana leaf or half coconut cups. Heat is retained in the $u m u$ by insulation with layers of leaves and sacks. Starch and coconut-cream mixtures are cooked by placing hot stones in the mixture which is held in a wooden tanoa (bowl). Considerable heat is generated, and is retained by the non-conducting material of the tanoa. The process would be less efficient if an enamel or metal bowl were used. There are usually one or two iron stoves in each village, mainly used for baking cakes and frying and roasting meat.

Thus, three types of cooking are used, baking, steaming and boiling. Some foods are fermented.

Cooking routine. Most families prepare an umu once a day. Formerly oven-cooking was carried out by boys and untitled men. To-day the Manono women and girls help with the work when necessary. Wood is brought in by the men and women and children 
gather leaves and smaller sticks. Each individual has his or her definite job and there is seldom any discussion as to what shall be done next. The number of helpers needed to make an $u m u$ for a family of from twelve to fifteen persons is two or three young men, two children and possibly a woman.

$U m u$ cooking requires considerable organization of labour, and technical efficiency. The length of time required for cooking depends on the efficiency of the workers and, as in all societies, the quality of the food depends largely on the skill of those who prepare and cook it. Efficiency is usually less when boys are responsible.

\section{Umu-making routine:}

(I) Four coconut logs are placed in a square. Coconut husks are placed between two sticks. Rocks are placed on the ground beneath. Sticks of hard wood are placed crosswise. The fire is lit and then more stones are put round the burning logs. The fire heats the stones for $\mathrm{I} h$.

(2) One man grates the coconuts on the asi or mata tuai (grater) into the tanoa (cooking bowl). It takes a young man about a minute to grate a coconut.

(3) Straining fibre is prepared from the coconut husk. The fibre is frayed out and washed; grated coconut is placed between layers of it and squeezed with a wringing action into a tanoa. The dry coconut is placed in a basket lined with coconut leaves.

(4) Coconut cream is poured into coconut cups which are balanced on the grated coconut in the basket until the $u m u$ is ready. When all the cups are filled a woman covers them with breadfruit leaves. The preparation of coconut cream takes about $20 \mathrm{~min}$.

(5) A woman removes half the mid-rib of a banana leaf with her teeth and prepares some tying fibre. She wilts the leaf on the fire till the edges curl, and holds the ends of the leaf together while a man pours in the cream. She then ties the end up. This dish is called fai'ai. It is made as a sign of respect for the head of the family; on one occasion observed another fai' ai was prepared for a carpenter who was making a tanoa for the family.

(6) The dry coconut is later used as pig food, or is sprinkled on the fire to make it burn.

(7) One man and a boy prepare the breadfruits which are supported on a pointed stick stuck in the ground. A half coconut with a sharp edge is used for rough grating of the green skin. Just before the $u m u$ is ready the breadfruits are grated finely to remove all the green outside skin. They are washed, split in half with a hard-wood axe, and covered with breadfruit leaves in a basket. It takes $\mathrm{I} \frac{1}{2} \mathrm{~min}$ to prepare a bread-fruit.

(8) When the stones are red-hot they are scraped out of the fire and any unburned wood is removed. A layer of hot stones is left as a base for the oven. Halves of breadfruit are arranged on the stones with the larger pieces in the middle where the heat is better conserved. Small stones are placed with tongs over the fruits. The smaller breadfruit halves are placed with the fish and meat in the next layer which is partly covered with stones. The cups of cream and fai' $a$ ire balanced on the stones, and the heap is covered with leaves of breadfruit and taro with tow sacks on the top. The $u m u$ is left for $\mathrm{I} \frac{1}{2}$ to $2 \mathrm{~h}$, depending on the contents. 


\section{Other methods of preparation}

Pot-cooking is done largely by women. The fireplace is built in a separate cooking fale, usually near to the umu fale (cooking house). The pots are hung over the hot coals on iron rails. Pot-cooking is used for boiling bananas and rice and for making soup, and is a favourite method for quick meals.

Fermentation pits are used for preparing a food called Samoan biscuit. A pit from 4 to $5 \mathrm{ft}$. deep is dug and lined with banana leaves, and bananas or breadfruit are placed in it and covered with leaves. The pit is filled to within 18 in. of the top with earth and the fruits are left for Io days to ferment. In former times some of the fermented food was eaten raw, but early medical advice discouraged the practice, probably because of the unpleasant smell when the pit was opened. Nowadays the food is mixed with coconut cream and, in pieces of about $3 \mathrm{lb}$., is spread on banana leaves and baked in the $u m u$ to a fairly hard consistency. Stored in a box, it will keep for a month or more.

Cooking utensils. Home-made wooden utensils are widely used in Manono and other remote places. Near the town, enamel and metal bowls are more in evidence. At least one wooden bowl is used in all phases of food preparation. Baskets are used for carrying and storing food and most families own one or two large iron pots and kettles. Barrels, drums and buckets are owned by the more wealthy families and are used for carrying and storing fresh water. Scrapers are made from half a coconut or sometimes a sharp-edged shell is used. Coconut meat is grated on a metal grater. A hard-wood axe is used for splitting breadfruit, and metal plantation-knives are used to open coconuts. The Samoan knife is a flexible blade made from the rib of a coconutpalm leaf. It is used for cutting out pieces of pounded breadfruit. Tanoa te koko is a wooden mortar. A stone pestle is used for pounding roasted cocoa beans.

Food is usually mixed with the hands and eaten with the fingers from a food mat, which is a small, oblong plate $18 \times 12$ in., made from woven coconut leaves. Sometimes a Samoan knife or fork is used, the fork being a thin rib of a single palm leaflet. Spoons and cups are the most widely used utensils and are particularly useful for eating the more recently-adopted foods, such as soup, chop-suey and stew. Most families own several cups, plates, saucers, glasses and glass jugs, which are kept for serving guests.

\section{Food storage}

Harvested foods are seldom stored for long. Cooked foods are kept from one meal to the next hung from the house ceiling in baskets lined with breadfruit leaves. Pigs, fowls and ducks are sometimes stored alive in small cages raised from the ground. Animal foods are usually eaten fresh, or they may be partly cooked and kept till the following day in baskets. A few fales have a nearby safe fale where food and copra may be kept. The safes are built off the ground and floors and windows are protected with gauze or netting. Most families have a fly-proof cabinet, which is used for storing the European eating utensils more often than for food. 


\section{Changing food habits}

Food habits seldom remain stationary in any community. Many factors, such as plenty, scarcity, association with people who eat different foods, and the social prestige attached to different dishes, cause changes to come about.

In the villages near Apia the basic meal pattern remains the same as in the more remote places, but there is a greater tendency to replace roots and fruits with white bread. The change is easily made because bread bears a close resemblance to traditional foods. The accompanying relish tends also to deteriorate in quality. Instead of coconut cream and sea foods, jam and sweet tea are frequently used. The people still buy tinned and fresh meat and fish, but they do not occur in the daily diet with the same regularity as the reef and plantation foods do in the remoter villages. The ease of preparation and of obtaining European foods in exchange for money has done much to make them popular.

In a busy banana-plantation area in Upolu, rice is valued because it can be prepared quickly in the early morning before the men and women go off to the plantation. Kopai is another quick breakfast food. It is made by boiling a white flour dough in water flavoured with caramelized sugar. In the same village the trader started a bakery, but it was not profitable because the orders were too irregular. On some days large amounts of bread were bought, or he might sell none for weeks. Such behaviour suggests a preference for taro and breadfruit when obtainable. The uniform flavour of Samoan foods possibly makes the people enjoy changes in texture more readily than Europeans do. They seem to like frequent changes in the basic starchy foods which may result from the seasonal changes in the availability of breadfruit. It is noticeable that Samoans buy bread in an amount which in appearance will replace a family meal of taro or breadfruit.

There are considerable differences in the nutrient content of the starchy foods, bread, taro and rice. Bread and rice have more than twice the calorie value of taro but the last provides twice the amount of thiamine/Cal., and contains fair quantities of other nutrients including the daily requirement of ascorbic acid.

A Samoan diet based on roots or breadfruit supplies ample amounts of thiamine. A failure to provide a minimum of $0.23 \mathrm{mg} / 1000$ non-fat Cal. might lead to deficiency. White rice and bread contain enough thiamine for the metabolism of their carbohydrate, but if the individual eats as well large amounts of sugar, arrowroot or cassava flour which are deficient in thiamine, the balance will be upset, and deficiency signs might be expected. When taro, other native roots, breadfruit or brown rice are the basic source of energy, they provide extra thiamine for the metabolism of vitamindeficient starchy foods that may form part of the diet. The urban food pattern always contains a large proportion of calories derived from refined carbohydrate, and when supplies of fish and vegetables are not available as supplements, the diet is liable to become deficient in thiamine. Outbreaks of beriberi have occurred among labourers in different parts of the Pacific from time to time.

Two foreign cooked foods that have gained popularity are cake and Chinese chop-suey. Since the introduction of cake, eggs have increased in importance, but 
most people think of eggs merely as an ingredient of these favoured foods. Chop-suey was introduced by the Chinese settlers and labourers, and its popularity has been increased by the Apia restaurants which are owned mainly by Chinese or Chinese half-breeds. The original dish consisted of chicken boiled with soy sauce and noodles. In flavour and consistency it is not unlike many Samoan foods. In order to make more profit the restaurants have replaced part of the meat with vegetables. The resulting mixture has a good nutritive value.

In conclusion it may be said that food patterns have not changed much in Samoa, but nutrition schemes should take the existing trends into account.

\section{Patterns of child rearing, family life and their effect on nutrition}

Family life. In most villages the labour of young married women is economically important. Weaving mats, collecting and drying sugar-cane for the fale thatch, making clothes, washing, ironing, and weeding the plantation, are all done by women. During the early years of married life, when the family may be establishing a plantation, the women spend more time on outside work and less on the household than in later years. As the children grow up, and food comes in more regularly from the plantation, the woman is able to hand over part of her outside work and devote more time to the care of children, mat-weaving and washing.

The husbands seem to consider that the plantation should come first. In one district the nurse always liked to talk to the woman when the husband was present. She would say to the man 'You must let your wife stay home and care for the baby'. Apparently the advice given to the woman when alone has little influence on the husband's demands for her labour. When the mothers are absent the infant is left in the care of the old women or younger children. It is not uncommon to find a baby left screaming at home all day with a brother or sister $4^{-8}$ years old.

Many mishaps, such as burns and cuts, occur when the crawling infant is left unwatched. The younger children of the family have a much better chance of survival when their sisters become old enough to look after them. Girls of 6-12 years spend a great part of their time in carrying round the baby. At mealtimes they bring the food to the younger children, and in some families the baby is placed between two older girls who feed it. The work of boys and girls benefits the nutrition of the younger children, for they spend hours collecting small shellfish, sea-urchins and seaweed from the reef at low tide. Boys fetch coconuts and all children hunt for eggs. When the children are in school the grandmother cares for the baby.

In some areas women have more leisure. It was noticeable that on Manono the women did little fishing or plantation work, and child accidents seemed to be fewer than in the Upolu villages.

Samoan children follow each other in regular succession. It is not uncommon for births to occur at intervals of a year or even less. After birth the baby is wrapped in cloth of which there may be three or four layers. It is laid on a mat with mosquito net or cloth on its face to keep the flies off. The net is seldom suspended so that, however hot, the infant is left perspiring under it on the fale floor. On a special 
occasion, such as a meeting of the Women's Committee, the clothing may be more formal. Some mothers even tie bags round the infant's hands in order, it is said, to prevent it from scratching its face. The excessive perspiration under the bags causes a rash which soon becomes infected with scabies or impetigo.

In the first 2 months of life, the infant is often too heavily clothed and is liable to become dehydrated unless fed frequently. In most places the mother stays at home during this time. When the baby cries she picks it up. Nurses advise mothers to give the baby drinks of water, but there was little evidence that they did so except where older women were bottle-feeding adopted infants. As the infant becomes more active less emphasis is placed on clothing. Strong infants of $3^{-20}$ months may remain naked for most of the day.

Infant-feeding practices. The infant is breast fed whenever it cries. Despite instructions from the district nurses to wean the baby at 9 months, the age recommended for weaning in New Zealand, most mothers continue to give the breast, sometimes up to 20 months. Breast feeding is usually stopped when a woman knows she is pregnant; it is commonly thought that the child will become sick and die if the mother then continues to feed it. Possibly this 'sickness' is simply due to starvation, although the women seem to regard the breast milk as poisonous.

Weaning is often very sudden. One day the infant is breast fed and the next is given taro, banana and fish. The nurses recommend the mothers to give chicken soup, pawpaw soup, egg, fish cooked in coconut cream, mashed taro, breadfruit, ripe banana, fish livers and cooked fish. When the average Samoan mother is questioned about the baby's weaning diet, she will recite this list of foods, and other women will prompt her with suggestions they may have heard from the nurses at Committee meetings. It is possible to prepare an excellent weaning diet from Samoan village foods, but there are many cultural and economic factors which adversely affect the food of the child between $I$ and 2 years old. Some of the difficulties encountered in providing the weaning diet as recommended are set out in Table 2. Since there is no fresh cow's milk in the villages, Samoan baby foods have a low content of protein and calcium so that it is difficult to supply an adequate substitute for breast milk. Breast feeding, should therefore, be encouraged up to the age of 12 months at least.

In some places the mothers chew foods like taro and pawpaw and put them in the baby's mouth. They do so up to weaning time. The practice is strongly discouraged by the district nurses and medical practitioners*, and by the better educated Samoans, but many mothers fail to soften the food in any other way, and often the baby gets only a hard lump of taro or banana.

Mead (1929) found that the women of Manua gave their babies extra foods from the Ist week, including pawpaw, coconut milk and sugar-cane juice. The food was chewed by the mother and put into the baby's mouth on her finger or, if it was liquid, the baby was allowed to suck a piece of bark cloth (tapa) dipped in it. The indigenous system of adding extra foods to the infant's diet at an early age agrees with the practice of most modern paediatricians. It appears that medical education has emphasized hygiene to the detriment of the infant's nutrition. Obviously it is unwise to give

* Samoan Assistant Medical Practitioners are trained at the Central Medical School, Suva, Fiji. 


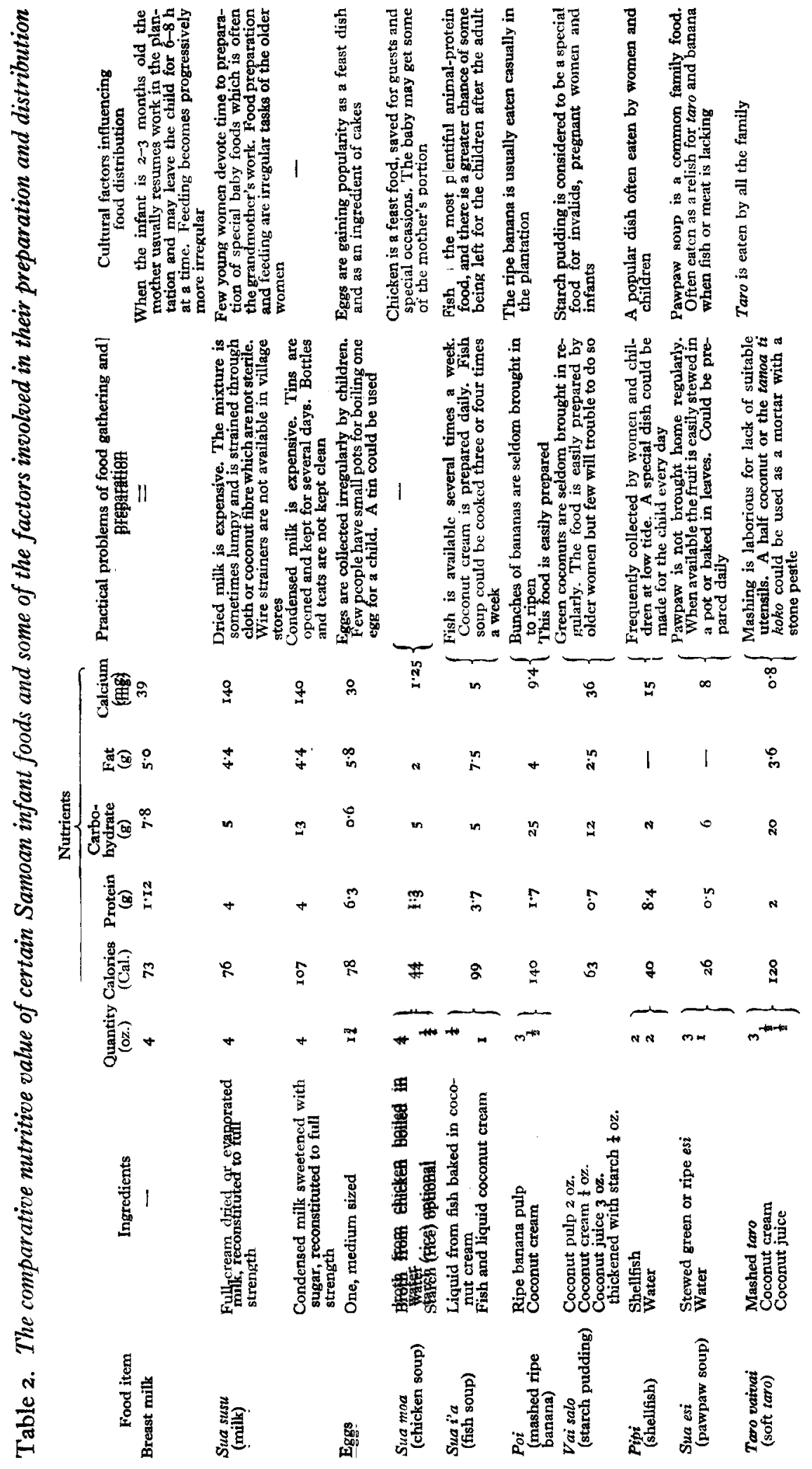


masticated foods, but the mother should be taught to adhere to the old feeding pattern, changing only the method of presentation. In native communities a single process, consisting of two parts, such as giving extra foods and masticating them, may be considered as one function by the people. If the one part of the process involved in chewing the food is discouraged, the whole function may be abandoned. It is therefore important to consider the parts of the process and provide suitable substitutes for those that have to be discouraged.

It is a common belief that 'mouth-to-mouth' feeding is of value in sickness. The mother thinks that by chewing the food she may pass on her own strength to the child.

After weaning young children may be fed by the mother, grandmother or an elder sister. The baby's nutrition depends on the attention given to it by its companions at meals. Samoan families vary in their care for the young child as much as European families do. The mother usually sits with the infant beside her and selects pieces of food for it from her mat. Some mothers are greedy for the protein foods, such as fish, meat and shark's liver, and the infant then gets little but a piece of taro or banana.

The Samoan way of eating requires considerable dexterity. Different kinds of food are placed on the mat which is covered with breadfruit or banana leaves. Soft and liquid foods may be wrapped in banana leaf or placed in a coconut cup or mug. The starchy foods, such as breadfruit and taro, are picked up in the fingers and dipped into the relish which may be soft fish or coconut cream or palusami (taro leaves cooked in coconut cream). The more dexterous the eater, the greater is the amount of relish that can be picked up. Young children lack skill, and have no palate so that a child may make a meal from a single food. Hard foods like baked green banana and whole taro take longer to eat and, while the young children are lazily chewing, the mother or older children may have eaten all the more nutritious and tasty protein foods.

The listless, poorly nourished children make little effort at mealtimes, but the healthy infants are much more enterprising and put their hands into all the different dishes. At the Women's Committee meetings some 6-month-old infants appeared to be quite alive to the differences in foods and, by their ingenuity, amused the members of the Committee who offered them titbits from their mats. The attractive, healthy children thus tended to be better fed than the listless ones. It is not intended to suggest that Samoan children are different from American children (Davis, I933), and would not choose an adequate diet if they had the chance.

The development of the child. The child from 4 years onwards can pick up odd foods from the reef or plantation. On Manono, children were seen chewing sugar-cane and the green husk of a coconut. When old enough they crack a coconut open with a cane knife and eat the contents while waiting for breakfast to cook in the $u m u$. Shellfish and the body and legs of little crabs are eaten during gathering expeditions. Adults and children prefer the insides of crabs and lobsters. The sea slug (loli) is liked by older children and adults; it is rubbed on the rocks and then slit open with a knife. Other sea foods that children collect are shellfish (pipi, puei, aliau), sea-urchins and edible seaweeds. At the age of from 8 to ro years, most boys can use a Shanghai spear to catch from the rocks larger creatures such as stone-fish and lobster. They seem to know how to deal with poisonous fish. A group of Manono children ranging from 
4 to ro years was seen fishing in a team. The younger children collected little shellfish and when they found a poisonous stone-fish a boy of Io years went for a spear. As the children grow older they collect from a wider area. On visits to the plantation they eat bananas, pawpaw and other fruits.

The importance of the nutrients gained from these casual munchings may be judged by comparing the nutritional status of children living on the island of Apolima with those in the Manono village of Apai which directly faces Apolima 2 miles across the sea. Apolima is a volcanic crater surrounded by steep cliffs with only one small reef about $100 \mathrm{yd}$. long at the entrance to the lagoon to be fished by the 249 inhabitants. In the plantations on the steep slope behind the village, yams, taro, breadfruit and coconuts are grown. There are no stores in the village, and no launches call regularly. Most of the fishing is done in the Manono fishing grounds several miles away. Ninety-three of the children were examined and twenty-seven had pronounced dental caries, twenty-five had severe gingivitis, and only twenty-eight were rated as having good nutrition, the criteria being good posture, clear eyes and skin, good hair, the appearance of normal weight, no winged scapulae or rachitic rosary and no obvious signs of anaemia. In the same village the Director of Health (personal communication) found a sex difference in the distribution of gingivitis. He attributed the high incidence among the young girls partly to the fact that they stay about the village, while the boys accompany the men to the plantations, where they eat fruit and chew hard foods like sugar-cane. The generally poor level of nutrition may be attributed to the diet which consists mainly of taro and yams. The people get less protein and calcium than on Manono because of the difficulty in reaching the fishing grounds and the scarcity of reef foods. On Apolima compared with Apai the people are poor. They get less from sales of copra and no cocoa is grown. All trade is carried on by the five fautasis (long-boats) which ply to and from Manono or Upolu. Twenty-five children were examined in the Manono village of Apai which supports a small community. It is built in the middle of a long reef-enclosed beach. There is an excellent fishing ground near by, and shellfish, seaweed and crabs may be collected daily from the reef. Only two of the children had obvious caries and one had slight gingivitis. The nutrition rating for twenty-three was good, and for two medium.

Among the girls, child-bearing may take place from 15 years onwards. At Lefaga there were several young mothers who appeared anaemic after the birth of their second or third infant.

\section{DISCUSSION AND RECOMMENDATIONS}

Many of the Samoan nurses complain that the village mothers are lazy and not interested in the welfare of their children. The complaint does not seem to be justified but, if the family unit is to survive, the poorer the family, the more time the mother and children must spend in producing food. As wealth increases the mother has more leisure to care for the young children and the home. The nurses say that the wives of traders and pastors make good mothers, but they are the women who enjoy greater economic security, and are at the same time in more frequent contact with European ideas on child raising. 
Disregard of the nurses' instructions may be because the health rules are incompatible with the established routine of family life. In a society largely patriarchal in outlook, new ideas, especially if they come from a woman, may cause ridicule. On the other hand, encouragement of a beneficial habit will seem sensible to them. The success which usually follows even a slight improvement in child-rearing practices gives the people confidence to try a more radical idea, and in time the villagers may be gradually taught to improve their standard of health.

The nutrition of the Samoan people is good as a whole. Those who suffer from the present feeding practices are the young children, and some families who live in the urban area of Apia. A lack of protein seems to be the main cause of poor nutrition in young children.

With the young child's welfare in mind the following recommendations are made.

A simple course in child welfare might be given at school or in a Junior Women's Committee to the girls from 6 to 12 years old. There is no reason why they should not learn to give the infant drinks of water, make daily collections of eggs or shellfish for the baby and see that its food is mashed and mixed with coconut cream and fish at mealtimes.

Grandmothers and older women with more leisure, when left to care for the infants, should be encouraged to prepare the traditional baby foods.

Every family should be encouraged to have a small pot or cooking container improvised from a meat tin for preparing small and frequent meals for the young child. Eggs or shellfish could then easily be cooked during the day by old women or young girls.

Mothers and girls might be trained to put some food aside in a mug or half coconut; it could be mashed with a fork or stone and given to the baby by an older child.

The District Nurse, who has close contact with the people through the Women's Committee, could be provided with educational material describing simple and practical ways of supplementing the infant's diet.

Recently Samoan nurses have been given a pamphlet describing the best ways of supplementing the infant's diet, and a technical school has been opened where girls will receive instruction in home crafts and infant care. Reproductions of posters issued by the Public Relations Office for the South Pacific Health Service are given in Pl. $\mathbf{I}$.

\section{SUMMARY}

I. A study of Samoan nutrition was made on the islands of Manono and Upolu in December 1950 and January 1951 .

2. Methods were developed for collecting information about the nature of the diet. Many visits were paid to individual households at times including those when food was being eaten and prepared.

3. The social background is described with the traditional methods of preparing and cooking the food.

4. The foods eaten were chiefly home-grown, but imported foods, particularly sugar, tinned meat and rice, were eaten to some extent.

5. Breadfruit, taro and green banana, all starchy foods, were the most important 


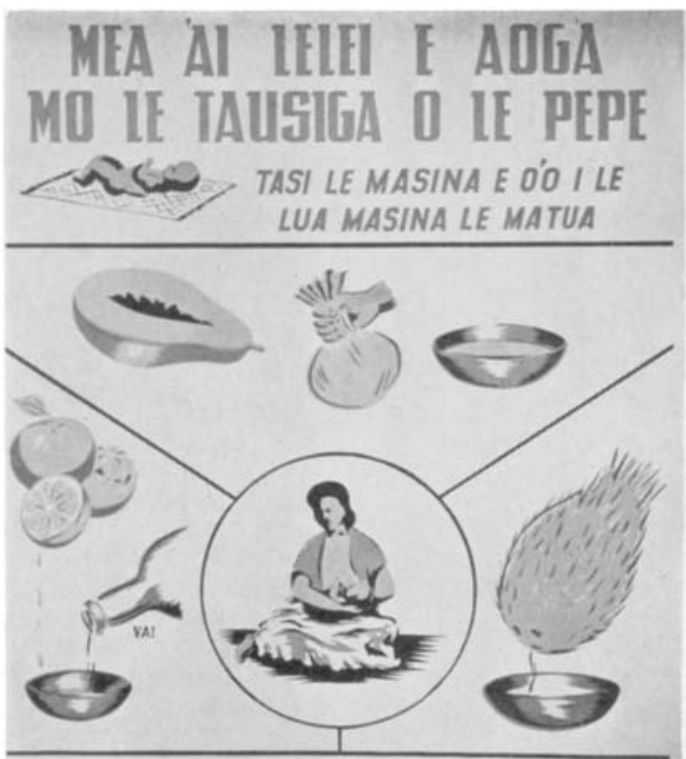

IA FA'APUINA IE VAI INU O IE PEPE

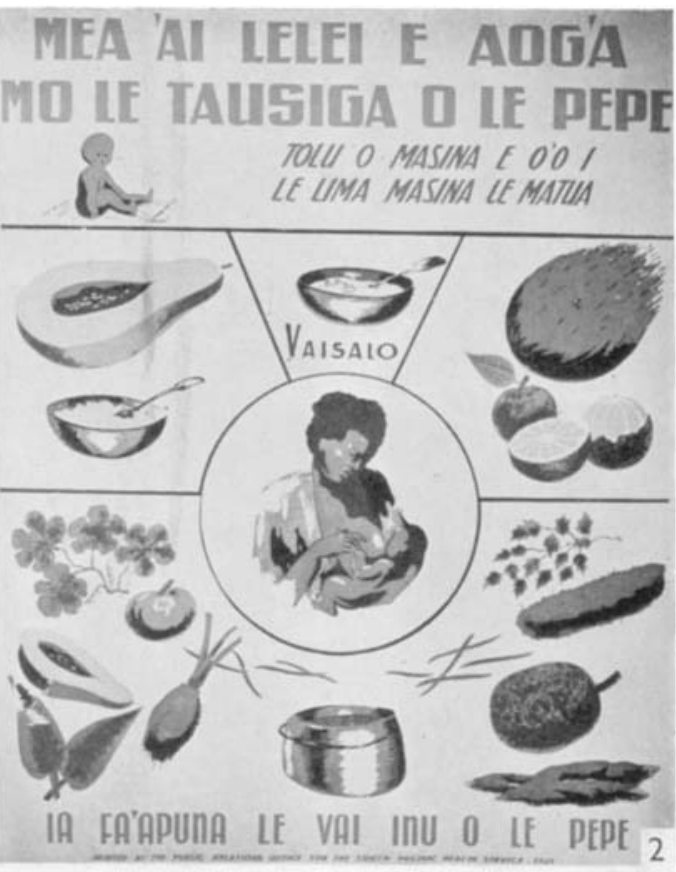

FAFANGA HO'D TAMASI'I

MEA AI IFIFI E ADTIA MI IF TAUISIGA D IE PEPE 2. ONO $D$ MASINA IF OOO I IF (2.) SEFUIU MAIF TASI MASINA
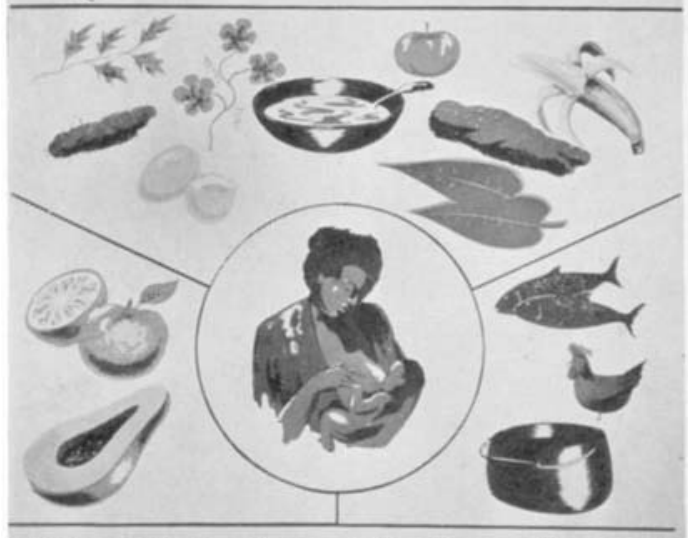

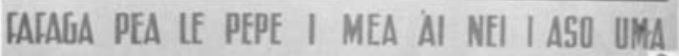

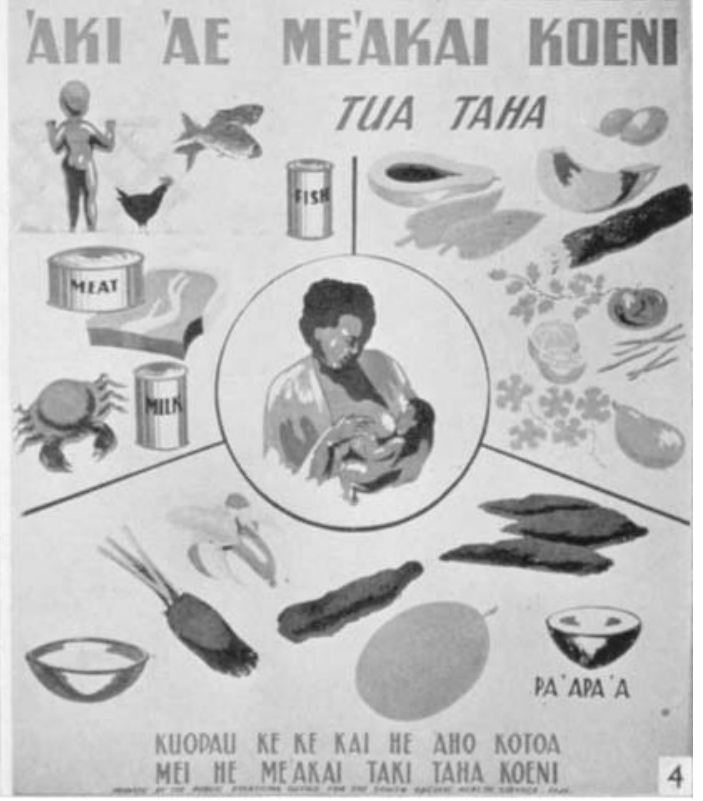

British Fournal of Nutrition, Vol. 8, No. 3 
home-grown sources of energy. There was no cow's milk, but fish, sheilfish and eggs supplied some animal protein, with small amounts of pork and chicken.

6 . The diet of the weanling child was the least satisfactory. Children were often given the breast up to 20 months of age, but the diet subsequently tended to be deficient in protein.

7. Although no fresh cow's milk was available, occurrence of kwashiorkor has not been recorded, and it is possible to provide an adequate weaning diet if sufficient trouble is taken, and full use is made of the available foods by preparing them suitably. Details are given of how such a weaning diet may be prepared.

8. Since nutritional status was much influenced by locality and custom, it is suggested that the nutrition of the infant might be improved if more consideration were given to village customs in Public Health and Child Welfare programmes for Samoa.

The author wishes to thank Dr J. M. Cruikshank, Inspector General, South Pacific Health Service, for permission to publish this paper. She would like also to thank Miss D. F. Hollingsworth, Principal Scientific Officer, Ministry of Food, who so kindly read the paper and offered many valuable suggestions.

\section{REFERENCES}

Bell, M. E. (1950). Report on Brief Survey of State of Nutrition of Samoans (Mimeo.).

Davis, C. M. (1933). Amer. F. Dis. Child. 46, 743.

Keesing, F. M. (1952). Personal communication.

Manson-Bahr, P. E. C. (1952). Docum. Med. geograph. trop. 4, 97.

Marples, M. J. (1950-1). Trans. R. Soc. trop. med. Hyg. 44, 319.

Mead, M. (1929). Coming of Age in Samoa. London: Jonathan Cape.

Richards, A. (1948). Hunger and Work in a Savage Community. Chicago: Free Press.

\section{EXPLANATION OF PLATE}

Top caption to all posters: Feed your child with these kinds of food. I. Top caption: from I to 2 months of his life. Bottom caption: boil his drinking water. 2. Top caption: from 3 to 5 months of his life. Bottom caption: as in poster I, 3. Top caption: from 6 to 1 I months of his life. Bottom caption: give these to the child every day. 4. Top caption: I year or over I year. Bottom caption: you must eat one food from each group every day. The first three posters are in Samoan, the fourth in Tongan. 